\title{
Pengaruh Motivasi dan Persepsi Biaya Pendidikan pada Minat Mahasiswa Mengikuti Pendidikan Magister Akuntansi
}

\author{
I Gede Agus Dicky Surya B. ${ }^{1}$ \\ I Gusti Ayu Nyoman Budiasih ${ }^{2}$
}

\author{
${ }^{1,2}$ Fakultas Ekonomi dan Bisnis Universitas Udayana (Unud), Bali, Indonesia \\ e-mail: dickysuryaaa@gmail.com
}

\begin{abstract}
ABSTRAK
Magister Akuntansi adalah pendidikan lanjutan pada perguruan tinggi untuk mendapatkan gelar master. Tujuan dari penelitian ini adalah untuk mengetahui pengaruh motivasi kualitas, motivasi karir, motivasi ekonomi, dan persepsi biaya pendidikan pada minat mahasiswa mengikuti pendidikan Magister Akuntansi. Populasi dalam penelitian ini adalah seluruh mahasiswa akuntansi regular pagi dan regular sore Fakultas Ekonomi dan Bisnis Universitas Udayana angkatan 2015 sebanyak 298. Teknik pengumpulan sampel yang digunakan adalah metode purposive sampling. Jumlah sampel yang ditentukan adalah sebanyak 171 sampel. Metode pengumpulan data menggunakan kuesioner. Teknik analisis data yang digunakan adalah analisis regresi linear berganda. Hasil analisis menunjukkan bahwa motivasi kualitas, karir, dan ekonomiberpengaruh positif pada minat mahasiswa mengikuti pendidikan Magister Akuntansi, sedangkan persepsi biaya pendidikan berpengaruh negatif pada minat mahasiswa mengikuti pendidikan Magister Akuntansi.

Kata kunci: Motivasi kualitas, motivasi karir, motivasi ekonomi, persepsi biaya pendidikan, minat mahasiswa.
\end{abstract}

\begin{abstract}
Master of Accounting is a secondary education in higher education to get a master's degree. The purpose of this study was to determine the effect of quality motivation, career motivation, economic motivation, and perceptions of education costs on the interest of students attending the Master of Accounting education. The population in this study were all accounting students at the Faculty of Economics and Businessclass of 2015 many as 298. The sampling technique used was purposive sampling method. The number of samples determined is 171 samples. Methods of collecting data using a questionnaire. The data analysis technique used is multiple linear regression analysis. The results of the analysis show that quality, career, and economic motivation have a positive effect on students' interest in taking part in the Accounting Master's education, while the perception of education costs has a negative effect on the interest of students attending the Master of Accounting.

Keywords: Quality motivation, career motivation, economic motivation, perception of education costs, student interest.
\end{abstract}

\section{PENDAHULUAN}

Bidang ilmu pengetahuan pada era globalisasi berkembang sangat cepat, tidak terkecuali bidang ilmu pada akuntansi, karena bidang akuntansi sangat berkaitan erat dengan dunia bisnis. Hal ini menyebaban dibutuhkan keterampilan untuk 
I Gede Agus Dicky Surya B. dan I Gusti Ayu Nyoman Budiasih. Pengaruh ...

meningkatkan kualitas serta profesionalisme guna menghadapi persaingan dalam dunia kerja seorang akuntan. Ada berbagai alasan mengapa mahasiswa memilih program studi akuntansi, misalnya prospek kerja yang menjanjikan di masa yang akan datang, peningkatan ekonomi, penghargaan dari masyarakat dan lain lain (Ismail \& Lestari, 2013). Jurusan akuntansi banyak diminati karena sarjana akuntansi memiliki paling sedikit tiga langkah alternatif yang dapat ditempuh. Pertama, setelah menyelesaikan program sarjana dalam jurusan akuntansi, seorang sarjana langsung dapat bekerja. Kedua, setelah menyelesaikan program sarjana dapat langsung melanjutkan ke jenjang pendidikan S2. Ketiga, setelah menyelesaikan program sarjana, seorang sarjana dapat melanjutkan pendidikan profesi (Aryani \& Erawati, 2016).

Pendidikan S2 sangat diperlukan pada era globalisasi ini. Trisna Wardhani menyatakan kuliah S2 memberikannya kesempatan untuk mengikuti berbagai macam acara dengan orang-orang penting yang bisa jadi akan menjadi mitra kerjanya di masa depan. Cathy Liu juga mengatakan aspek yang dipelajari dalam menempuh S2 membantu dalam pengembangan karir, selain itu pendidikan S2 dapat memberikan pendapatan yang lebih potensial daripada pendapatan seorang S1 setiap tahunnya (Kompas, 2013). Salah satu profesi yang mensyaratkan harus S2 yaitu dosen.

Profesi dosen sangat dibutuhkan di masa depan. Syarat untuk menjadi dosen yaitu memiliki gelar Magister. Ghufron selaku Direktur Jendral Sumber Daya Iptek dan Dikti mengatakan untuk merekrut lulusan terbaik menjadi dosen muda, karena para dosen masih didominasi dari generasi yang berumur 37-52 
tahun sebanyak 142.020 orang sedangkan dosen yang rentang usia hingga 36 tahun sebanyak 113.965 orang. Padahal dosen yang pensiun per tahun sekitar 2.000 orang. Menteri Riset, Teknologi, dan Pendidikan Tinggi Mohamad Nasir menyatakan agar PMDSU bisa dikembangkan lagi dengan merangkul calon dosen dari sejak mahasiswa S1 (Kompas, 2018).

Dewasa ini lulusan sarjana S1 sudah sangat banyak dibandingkan dengan kondisi jumlah sarjana 5 tahun lalu. Februari 2012, proporsi pengangguran yang memiliki tingkat pendidikan terakhir sarjana $\mathrm{S} 1$ tercatat sebesar 7,1\% terhadap total pengangguran Indonesia. Porsi ini meningkat menjadi $8,7 \%$ pada Februari 2017. Selain itu, tingkat pengangguran dari lulusan diploma/akademi juga menunjukkan proporsi yang meningkat. Februari 2012, ada 3,3\% pengangguran disumbang dari pendidikan diploma/akademi dan meningkat menjadi 3,6\% pada Februari 2017 (Purnamasari, 2017). Pendidikan sarjana saja tidaklah cukup untuk dapat bersaing secara kompetitif dari para tenaga kerja lainnya, terutama tenaga kerja asing yang siap bekerja di Indonesia khususnya Bali. Hal tersebut membuat gelar magister penting untuk dimiliki oleh para tenaga kerja agar dapat lebih kompetitif dalam persaingan mencari kerja, selain itu untuk mendapatkan pangkat tertentu di suatu instansi pemerintah atau BUMN, tingkat pendidikan menjadi salah satu indikator penting.

Magister akuntansi adalah pendidikan lanjutan pada perguruan tinggi untuk mendapatkan gelar master. Pendidikan ini harus dijalani setelah selesai menempuh pendidikan program sarjana S1 Jurusan Akuntansi. Salah satu universitas di Provinsi Bali yang menyediakan program pendidikan magister 
akuntansi yaitu Universitas Udayana, dengan ijin penyelenggaraan No. SK Pendirian PS: No. 3538/D/T/2007 tanggal 5 November 2007.

Tabel 1.

Perkembangan Mahasiswa Magister Akuntansi Fakultas Ekonomi dan Bisnis Universitas Udayana

\begin{tabular}{cc}
\hline Tahun & $\begin{array}{c}\text { Jumlah Mahasiswa } \\
\text { Magister Akuntansi }\end{array}$ \\
\hline 2016 & 67 \\
2017 & 74 \\
2018 & 73 \\
\hline
\end{tabular}

Sumber: Fakultas Ekonomi dan Bisnis Universitas Udayana, 2018

Berdasarkan Tabel 1bahwa adanya perkembangan mahasiswa magister akuntansi dari tahun 2016-2018. Hal inilah yang memotivasi dilakukannya penelitian mengenai pengaruh Motivasi kualitas, motivasi karir, motivasi ekonomi, dan persepsi biaya pendidikan pada minat mahasiswa mengikuti pendidikan magister akuntansi. Ada banyak faktor yang mempengaruhi minat mahasiswa untuk mengikuti pendidikan magister akuntansi, seperti penelitian yang dilakukan oleh Devani (2015) yang meneliti motivasi kualitas, motivasi karir, dan motivasi ekonomi. Berdasarkan faktor tersebut, dalam penelitian ini akan meneliti beberapa faktor yang dapat meningkatkan minat mahasiswa untuk mengikuti pendidikan magister akuntansi yaitu motivasi kualitas, motivasi karir, motivasi ekonomi, dan persepsi biaya pendidikan.

Motivasi kualitas merupakan dorongan yang timbul dalam diri seseorang untuk meningkatkan kualitas diri dan kemampuannya dalam bidang yang ditekuninya sehingga dapat melaksanakan tugas yang baik dan benar (Kusumawati \& Waluyo, 2013). Kualitas yang dimiliki setiap orang berbeda-beda hal ini dapat ditunjukan dengan kuantitas dan kualitas motivasi, yang dimaksud 
dengan kuantitas motivasi yakni seberapa banyak seorang individu menerima motivasi dari individu lain, sedangkan kualitas motivasi adalah seberapa berpengaruh motivasi yang diberikan oleh orang lain terhadap individu itu sendiri(Johnson, 2009). Motivasi dapat dikatakan sebagai dorongan untuk meningkatkan kualitas agar memicu keinginan untuk mengikuti suatu pendidikan (Bozek, Raeymaeckers, \& Spooren, 2017).

Motivasi karir juga menjadi salah satu faktor yang membuat calon mahasiswa pendidikan magister akuntansi menempuh pendidikan akuntansi. Hal tersebut dikarenakan dengan menyelesaikan pendidikan akuntansi di magister akuntansi, diharapkan jenjang karir yang dimiliki calon peserta bisa lebih baik. Pendidikan yang lebih spesifik diharapkan membuat calon peserta bisa menjadi salah satu karyawan perusahaan yang memiliki keahlian yang baik di bidang akuntansi dan mendapatkan jenjang karir yang lebih menjanjikan.

Motivasi ekonomi merupakan suatu dorongan yang timbul dari dalam diri seseorang untuk meningkatkan kemampuan pribadinya dalam rangka mencapai penghargaan finansial yang diinginkannya. Penghargaan finansial ada dua yaitu penghargaan langsung dan tidak langsung. Penghargaan langsung meliputi pembayaran yang berasal dari upah dasar atau gaji pokok, upah lembur, atau jasa produksi yang didapat perusahaan, sedangkan penghargaan tidak langsung meliputi asuransi, atau program pensiun (Dyastari \& Yadnyana, 2016). Sehingga semangat motivasi ekonomi yang tinggi akan mempengaruhi seseorang untuk mengikuti pendidikan magister akuntansi. 
I Gede Agus Dicky Surya B. dan I Gusti Ayu Nyoman Budiasih. Pengaruh ...

Biaya yang diperlukan oleh peserta pendidikan magister akuntansi ditentukan oleh universitas tempat mahasiswa tersebut ingin menempuh pendidikan magister akuntansi. Salah satu universitas di Provinsi Bali yang menyediakan program pendidikan magister akuntansi yaitu Universitas Udayana. Biaya pendidikan adalah semua pengorbanan finansial yang dikeluarkan oleh mahasiswa untuk keperluan pendidikannya dari awal sampai berakhirnya pendidikan. Manusia ingin mendapatkan keuntungan setinggi-tingginya dengan biaya serendah-rendahnya (Aryani \& Erawati, 2016). Semakin tinggi jenjang pendidikan maka akan semakin tinggi biaya yang harus dikeluarkan. Biasanya semakin berkualitasnya suatu instansi pendidikan maka biaya yang harus dikeluarkan juga akan semakin besar. Biaya pendidikan yang mahal telah menjadi masalah umum di kalangan masyarakat yang sedang menimba ilmu dan penghalang masuk bagi masyarakat yang berpenghasilan rendah.

Rendahnya minat mahasiswa akuntansi S1 untuk melanjutkan S2 dikarenakan berbagai alasan dari motivasi dan biaya pendidikan. Tidak adanya motivasi membuat mahasiswa memilih untuk tidak melanjutkan S2, tetapi jika ada motivasi yang datang dari internal maupun eksternal akan membuat mahasiswa untuk melanjutkan studinya ke pasca sarjana. Selain itu biaya untuk mendapatkan gelar master cukup besar. Mahasiswa yang belum mampu membiayai kuliah pasca sarjana akan memilih untuk bekerja terlebih dahulu daripada langsung melanjutkan pendidikan magister akuntansi. Masalah yang terdapat bagi calon peserta pendidikan magister akuntansi harus mempersiapkan dana kuliah yang 
lebih besar, dimana motivasi yang kuat dibutuhkan agar dapat menyelesaikan program pendidikan magister akuntansi dengan baik.

Menurut Tjiptono (2004), kualitas mempunyai definisi yang berbeda-beda antara pendapat satu ahli dengan ahli lainnya. Definisi kualitas yang sering dijumpai antara lain: kesesuaian dengan persyaratan atau tuntunan, kecocokan untuk pemakaian, perbaikan atau penyempurnaan berkelanjutan.

Berdasarkan definisi tersebut dapat disimpulkan bahwa Motivasi kualitas merupakan dorongan suatu usaha untuk menciptakan kegairahan dan mempengaruhi serta menggerakkan seseorang untuk meningkatkan kualitas dan kemampuannya di bidang yang ditekuninya sehingga menghasilkan kinerja yang baikpada suatubidang pekerjaan.

Gibson (2008) karir adalah rangkaian sikap dan perilaku yang berkaitan dengan pengalaman dan aktivitas kerja selama rentang waktu kehidupan seseorang dan rangkaian aktivitas kerja yang terus berkelanjutan. Dengan demikian karir seorang individu melibatkan rangkaian pilihan dari berbagai macamkesempatan. Jika ditinjau dari sudut pandang organisasi, karir melibatkan proses dimana organisasi memperbaharui dirinya sendiri untuk menuju efektivitas karir yang merupakan batas dimana rangkaian dari sikap karir dan perilaku dapat memuaskan seorang individu.

Menurut Andrian (2001) pengertian karir meliputi elemen-elemen obyektif dan subyektif. Elemen obyektif berkenaan dengan kebijakan-kebijakan pekerjaan atau posisi jabatan yang ditentukan organisasi, sedangkan elemen subyektif menunjuk pada kemampuan seseorang dalam mengelola karir dengan mengubah 
I Gede Agus Dicky Surya B. dan I Gusti Ayu Nyoman Budiasih. Pengaruh ...

lingkungan obyektif (misalnya dengan mengubah pekerjaan/jabatan) atau memodifikasi persepsi subyektif tentang suatu situasi (misalnya dengan mengubah harapan).

Simamora (2001) berpendapat bahwa kata karir dapat dipandang dari beberapa perspektif yang berbeda, antaralain dari perspektif yang obyektif dan subyektif. Dipandang dari perspektif yang subyektif, karir merupakan urut-urutan posisi yang diduduki oleh seseorang selama hidupnya, sedangkan dari perspektif yang obyektif, karir merupakan perubahan-perubahan nilai, sikap, dan motivasi yang terjadi karena seseorang menjadi semakin tua. Motivasi karir merupakan dorongan yang timbul dalam diri seseorang untuk senantiasa meningkatkan kemampuannya dengan tujuanmendapatkan jabatan atau karir yang lebih baik dari sebelumnya (Durso, 2016).

Motivasi ekonomi dapat diartikan suatu dorongan yang timbul dalam diri seseorang untuk meningkatkan kemampuan pribadinya dalam rangka untuk mencapai penghargaan finansial yang diinginkan. Penghargaan finansial merupakan salah satu bentuk sistem pengendalian manajemen untuk memastikan bahwa segenap elemen karyawan dapat mengarahkan tindakannya terhadap pencapaian tujuan perusahaan, maka manajemen memberikan balas jasa atau reward dalam berbagai bentuk termasuk didalamnya financial reward. Penghargaan finansial terdiri atas penghargaan langsung dan tidak langsung. Penghargaan langsung berupa pembayaran dari upah dasar atau gaji pokok, overtime atau gaji dari lembur, pembagian dari laba sedangkan penghargaan tidak 
langsung meliputi asuransi, tunjangan biaya sakit serta program pensiun (Siegel \& Marconi, 1989).

Mulyadi (2015:8) biaya adalah pengorbanan sumber ekonomi yang diukur dalam satuan uang, yang telah terjadi atau yang kemungkinan akan terjadi untuk tujuan tertentu, sedangkan Halim (2012:51) menyatakan biaya mengukur pengorbanan ekonomis yang dilakukan untuk mencapai tujuan organisasi. Biaya pendidikan didefinisikan sebagai semua jenis pengeluaran yang dikeluarkan untuk menyelenggarakan pendidikan (Wijaya, 2010). Biaya pendidikan sangat penting dalam penyelenggaraan pendidikan, karena tanpa dukungan biaya proses pendidikan tidak akan dapat berjalan. Dapat disimpulkan persepsi biaya pendidikan merupakan keseluruhan biaya yang dikeluarkan oleh mahasiswa untuk keperluan selama menempuh pendidikan dari awal sampai berakhirnya pendidikan.

Kualitas adalah tingkat baik buruknya sesuatu. Magister Akuntansi merupakan pendidikan yang dapat meningkatkan kualitas seseorang. Teori kebutuhan McClelland menunjukkan bahwa setiap individu dapat termotivasi oleh kebutuhan untuk berprestasi. Salah satu alasan seseorang bisa termotivasi dalam pengambilan keputusan adalah dalam rangka meningkatkan kualitas dan presetasinya (Robbins \& Judge, 2008).

Penelitian yang dilakukan Devani (2015) yang menyatakan bahwa Motivasi kualitas berpengaruh positif dan signifikan terhadap minat mahasiswa akuntansi dalam melanjutkan pendidikan magister akuntansi. Selajan dengan penelitian yang dilakukan oleh Verawati (2016) dan Yunerlya \& Siegel (2013) 
I Gede Agus Dicky Surya B. dan I Gusti Ayu Nyoman Budiasih. Pengaruh ...

yang menyatakan motivasi kualitas berpengaruh positif terhadap minat mahasiswa mengikuti pendidikan profesi akuntansi.

Kualitas dianggap suatu hal yang diperhatikan di dalam jenjang pendidikan. Semakin tinggi jenjang pendidikan yang telah ditempuh seseorang maka kualitas yang dimilikinya pun semakin baik. Motivasi kualitas dapat mempengaruhi minat seseorang dalam menempuh Magister Akuntansi dilihat dari banyak keuntungan yantg diperolehnya salah satunya yaitu dapat menjadi seorang dosen. Berdasarkan uraian tersebut, maka dapat dirumuskan hipotesis sebagai berikut:

$\mathrm{H}_{1}$ : Motivasi kualitas berpengaruh positif pada minat mahasiswa mengikuti pendidikan magister akuntansi.

Karir adalah pilihan seseorang yang berasal dari dalam dirinya, sehingga dapat menunjukkan kepribadian, motivasi, dan seluruh kemampuan yang dimilikinya. Teori kebutuhan McClallend menyatakan bahwa salah satu dari tingkat kebutuhan manusia adalah kebutuhan untuk kekuasaan. Karyawan yang memiliki dasar pendidikan akuntan yang lebih tinggi perlu waktu yang pendek untuk dipromosikan sebagai manajer. Magister akuntansi merupakan salah satu tahap pendidikan yang dapat memotivasi peningkatan karir.

Hal ini dibuktikan oleh penelitian Zyl (2011)yang menyatakan bahwa mahasiswa akuntansi yang memilih karir sebagai akuntan publik mengharapkan keamanan kerja, kepuasan kerja, keahlian akuntansi dan penghasilan di masa mendatang yang potensial. Penelitian yang dilakukanDevani (2015) menyatakan bahwa motivasi karir berpengaruh positif dan signifikan terhadap minat mahasiswa akuntansi mengikuti pendidikan magister akuntansi. Sejalan dengan 
penelitian yang dilakukan oleh Dewi \& Mediatrix (2018)menyatakan motivasi karir berpengaruh positif terhadap minat mahasiswa akuntansi reguler dan non reguler Universitas Udayana mengikuti PPAk.

Pendidikan magister akuntansi bisa menjadi salah satu faktor yang memotivasi peningkatkan karir. Seseorang akan termotivasi untuk meningkatkan karirnya karena berasumsi bahwa karir yang lebih tinggi akan dapat meningkatkan status sosial ekonomi dan mencapai kepuasan diri. Berdasarkan uraian tersebut, maka dapat dirumuskan hipotesis sebagai berikut:

$\mathrm{H}_{2}$ : Motivasi karir berpengaruh positif pada minat mahasiswa rmengikuti pendidikan magister akuntansi.

Teori McClelland menyatakan bahwa setiap individu memiliki kebutuhan akan kekuasaan termasuk kekuasaan keuangan. Motivasi ekonomi adalah suatu dorongan yang timbul dari dalam diri seseorang untuk meningkatkan kemampuan pribadinya dalam rangka mencapai pengahargaan finansial yang dinginkannya(Siegel \& Marconi, 1989). Secara umum penghargaan finansial terdiri atas penghargaan langsung dan tidak langsung. Penghargaan langsung meliputi pembayaran yang berasal dari upah dasar atau gaji pokok, upah lembur, atau pembagaian laba yang didapat perusahaan, sedangkan penghargaan tidak langsung meliputi asuransi, tunjangan-tunjangan, atau program pensiun (Dyastari \& Yadnyana, 2016).

Penelitian Devani (2015) menunjukkan bahwa motivasi ekonomi berpengaruh positif pada minat mahasiswa akuntansi mengikuti pendidikan magister akuntansi. Sejalan dengan penelitian yang dilakukan Aryani \& 
Erawati(2016) motivasi ekonomi berpengaruh positif terhadap minat mahasiswa mengikuti pendidikan profesi akuntansi.

Carpenter dan Strawser (1970) dalam Widyastuti \& Juliana (2004) dalam penelitiannya untuk mengetahui kriteria mahasiswa jurusan akuntansi di Pennsylvania State University dalam memilih karir. Hasil penelitian tersebut menunjukkan bahwa gaji awal merupakan karakter penting dari tiga karakter dalam pemilihan karir. Untuk mencapai kualitas ekonomi yang baik dalam bekerja diperlukkan peningkatan pendidikan agar keuntungan yang didapatkan dikemudian hari dapat lebih besar. Sehingga diperlukan motivasi terhadap minat tersebut untuk meningkatkan pernghargaan finansial dimasa yang akan datang. Berdasarkan uraian tersebut, dapat dirumuskan hipotesis sebagai berikut:

$\mathrm{H}_{3}$ : Motivasi ekonomi berpengaruh positif pada minat mahasiswa mengikuti pendidikan magister akuntansi.

Teori hukum permintaan menjelaskan tentang adanya hubungan yang bersifat negatif yang dikemukakan oleh Alfred Marshall yaitu, apabila harga naik maka jumlah barang yang diminta sedikit dan apabila harga rendah jumlah barang yang diminta meningkat (Aryani \& Erawati, 2016). Dalam hal ini apabila persepsi biaya pendidikan dianggap mahal maka minat mahasiswa mengikuti pendidikan Magister Akuntansi semakin rendah.

Persepsi biaya pendidikan merupakan biaya yang dikeluarkan oleh mahasiswa untuk keperluan selama menempuh pendidikan dari awal sampai berakhirnya pendidikan (Hadiprasetyo, 2014). Biaya pendidikan dikeluarkan untuk mendapatkan manfaat di masa yang akan datang. Hal inilah yang menyebabkan dalam mengeluarkan biaya diperlukan analisis biaya manfaat 
(Aryani \& Erawati, 2016). Ghozali (2016) analisis biaya manfaat adalah salah satu bentuk penafsiran investasi yang membandingkan antara biaya manfaat dan manfaat ekonomi dari suatu proyek sehingga manfaat yang didapat harus lebih dari biaya yang dikeluarkan.

Hal ini dibuktikan oleh penelitian yang dilakukan oleh Berlinasari \& Erawati (2017) bahwa biaya pendidikan berpengaruh negatif pada minat mahasiswa akuntansi mengikuti pendidikan profesi akuntansi. Hadiprasetyo (2014) persepsi biaya pendidikan tidak mempunyai pengaruh positif signifikan terhadap minat mahasiswa akuntansi Fakultas Ekonomi Universitas Negeri Yogyakarta untuk mengikuti PPAk, selain itu penelitian Sapitri \& Yaya (2015) biaya studi berpengaruh negatif signifikan terhadap minat mengikuti PPAk. Berdasarkan uraian tersebut, dapat dirumuskan hipotesis sebagai berikut:

$\mathrm{H}_{4}$ : Persepsi biaya pendidikan berpengaruh negatif pada minat mahasiswa mengikuti pendidikan magister akuntansi.

\section{METODE PENELITIAN}

Penelitian ini dilakukan pada di Fakultas Ekonomi dan Bisnis (FEB) Universitas Udayana. Objek penelitian adalah fenomena atau masalah penelitian yang telah diabstraki menjadi suatu konsep atau variabel (Silalahi, 2009). Objek dalam penelitian ini adalah pengaruh motivasi kualitas, motivasi karir, motivasi ekonomi, dan persepsi biaya pendidikan pada minat mahasiswa mengikuti pendidikan magister akuntansi.

Populasi dalam penelitian ini adalah seluruh mahasiswa akuntansi regular pagi dan regular sore Fakultas Ekonomi dan Bisnis Universitas Udayana angkatan 2015 berjumlah 298 orang. Kriteria yang digunakan untuk menentukan sampel 
I Gede Agus Dicky Surya B. dan I Gusti Ayu Nyoman Budiasih. Pengaruh ...

dalam penelitian ini adalah mahasiswa semester 7 pada tahun akademik 2015 yang masih aktif kuliah dengan alasan bahwa mahasiswa selama 6 semester telah menempuh pendidikan di prodi Akuntansi Fakultas Ekonomi dan Bisnis Universitas Udayana sehingga mereka sudah mengetahui dengan jelas setelah tamat akan melanjutkan pendidikan dan/ bekerja. Teknik pengambilan sampel dalam penelitian ini adalah teknik probability sampling.

Dalam menentukan jumlah sampel peneliti menggunakan rumus Slovin, yaitu:

$$
n=\frac{N}{\left(1+N e^{2}\right)}
$$

Keterangan:

$$
\begin{aligned}
& \mathrm{n} \quad \text { = jumlah anggota sampel } \\
& \mathrm{N}=\text { jumlah anggota populasi } \\
& \mathrm{e} \quad \text { = nilai kritis (batas ketelitian } 0,05) \\
& \qquad n=\frac{298}{\left(1+298(0,05)^{2}\right)}
\end{aligned}
$$

$\mathrm{n}=170,77$ dibulatkan 171

Teknik analisis data yang digunakan dalam penelitian ini adalah analisis regresi linier berganda. Persamaan regresinya adalah sebagai berikut:

$$
Y=\alpha+\beta_{1} X_{1}+\beta_{2} X_{2}+\beta_{3} X_{3}+\beta_{4} X_{4}+e
$$

Keterangan:

$\mathrm{Y}=$ Minat mahasiswa mengikuti pendidikan magister akuntansi

$\alpha=$ Konstanta

$\beta_{1}=$ Koefisien regresi Motivasi kualitas

$\beta_{2}=$ Koefisien regresi motivasi karir

$\beta_{3}=$ Koefisien regresi motivasi ekonomi

$\beta_{4}=$ Koefisien regresi biaya pendidikan

$\mathrm{X}_{1}=$ Motivasi Kualitas

$\mathrm{X}_{2}=$ Motivasi Karir 


$$
\begin{aligned}
& \mathrm{X}_{3}=\text { Motivasi Ekonomi } \\
& \mathrm{X}_{4}=\text { Persepsi Biaya Pendidikan } \\
& \mathrm{e}=\text { Error term }
\end{aligned}
$$

\section{HASIL DAN PEMBAHASAN}

Uji normalitas ini bertujuan untuk mengetahui apakah residual dari model regresi yang dibuat berdistribusi normal atau tidak. Dalam penelitian ini uji normalitas dilakukan dengan menguji normalitas residual dengan menggunakan uji Kolmogorov-Smirnov. Jika probabilitas signifikansi nilai residual lebih besar dari 0,05 maka data tersebut dikatakan berdistribusi normal. Demikian pula sebaliknya, jika probabilitas signifikansi residual lebih rendah dari 0,05 maka data tersebut dikatakan tidak berdistribusi normal.

Tabel 2.

\section{Hasil Uji Normalitas}

\begin{tabular}{cc}
\hline & Unstandardized Residual \\
\hline $\mathrm{N}$ & 146 \\
Kolmogorov-Smirnov Z & 0,655 \\
Asymp.Sig.(2-tailed) & 0,785 \\
\hline
\end{tabular}

Sumber: Data diolah, 2018

Berdasarkan hasil analisis uji normalitas didapat nilai signifikansi sebesar 0,785 seperti yang ditunjukkan oleh Tabel 2. Karena nilai signifikansi uji Kolmogorov-Smirnov lebih dari 0,05 maka dapat disimpulkan bahwa model persamaan regresi tersebut berdistribusi normal.

Uji multikolinearitas bertujuan untuk menguji apakah dalam satu model regresi ditemukan adanya korelasi antar variabel bebas. Model regresi yang baik adalah tidak terjadi korelasi diantara variabel bebas. Untuk mendeteksi ada atau tidaknya korelasi antar variabel bebas dapat dilihat dari nilai tolerance dan nilai 
I Gede Agus Dicky Surya B. dan I Gusti Ayu Nyoman Budiasih. Pengaruh ...

variance inflation factor (VIF), jika nilai tolerance lebih dari $10 \%$ atau VIF kurang dari 10, maka dapat dikatakan model telah bebas dari multikoleniaritas.

Tabel 3.

Hasil Uji Multikoleniaritas

\begin{tabular}{lcrc}
\hline \multicolumn{1}{c}{ Variabel } & Tolerance & \multicolumn{1}{c}{ VIF } & Keterangan \\
\hline Motivasi kualitas $\left(\mathrm{X}_{1}\right)$ & 0,332 & 3,013 & Bebas multikol \\
Motivasi karir $\left(\mathrm{X}_{2}\right)$ & 0,346 & 2,892 & Bebas multikol \\
Motivasi ekonomi $\left(\mathrm{X}_{3}\right)$ & 0,518 & 1,930 & Bebas multikol \\
Persepsi biaya pendidikan $\left(\mathrm{X}_{4}\right)$ & 0,874 & 1,144 & Bebas multikol \\
\hline
\end{tabular}

Sumber: Data diolah, 2018

Berdasarkan Tabel3 dapat dilihat bahwa nilai tolerance dan VIF dari seluruh variable tersebut menunjukkan bahwa nilai tolerance untuk setiap variabel lebih besar dari $10 \%$ dan nilai VIF lebih kecil dari 10 yang berarti model persamaan regresi bebas dari multikolinearitas.

Uji heteroskedastisitas ini bertujuan untuk mengetahui apakah dalam model regresi terjadi ketidaksamaan varians dari residual satu pengamatan ke pengamatan lain yang dilakukan dengan uji Glejser. Model regresi yang baik adalah yang tidak mengandung gejala heteroskedastisitas atau mempunyai varians yang homogen. Jika variabel bebas yang diteliti tidak mempunyai pengaruh signifikan atau nilai signifikansinya lebih dari 0,05 terhadap nilai absolute residual, berarti model regresi tidak mengandung gejala heteroskedastisitas. Hasil pengujian heteroskedastisitas disajikan pada Tabel 4.

Tabel 4.

Hasil Uji Heteroskedastisitas

\begin{tabular}{lcc}
\hline \multicolumn{1}{c}{ Variabel } & Signifikansi & Keterangan \\
\hline Motivasi kualitas $\left(\mathrm{X}_{1}\right)$ & 0,168 & Bebas heteroskedastisitas \\
Motivasi karir $\left(\mathrm{X}_{2}\right)$ & 0,562 & Bebas heteroskedastisitas \\
Motivasi ekonomi $\left(\mathrm{X}_{3}\right)$ & 0,424 & Bebas heteroskedastisitas \\
Persepsi biaya pendidikan $\left(\mathrm{X}_{4}\right)$ & 0,726 & Bebas heteroskedastisitas \\
\hline
\end{tabular}


Pada Tabel 4dapat dilihat bahwa nilai signifikansi dari variabel motivasi kualitas, motivasi karir, motivasi ekonomi, dan persepsi biaya pendidikanmasingmasing memiliki nilai yang lebih besar dari 0,05 yang berarti tidak terdapat pengaruh antara variabel bebas terhadap absolute residual. Dengan demikian, model yang dibuat tidak mengandung gejala heteroskedastisitas.

Perhitungan koefisien regresi linier berganda dilakukan dengan analisis regresi melalui software SPSS 18.0 for Windows, diperoleh hasil yang ditunjukan pada Tabel5.

Tabel 5.

Hasil Analisis Regresi Linear Berganda

\begin{tabular}{llccc}
\hline Model & Koefisien Regresi & Std. Error & $\mathrm{t}$ & Sig. \\
\hline 1 (Constant) & 0,000 & 0,057 & 0,000 & 1,000 \\
Motivasi kualitas & 0,209 & 0,099 & 2,100 & 0,037 \\
Motivasi karir & 0,300 & 0,097 & 3,079 & 0,002 \\
Motivasi ekonomi & 0,247 & 0,080 & 3,109 & 0,002 \\
Persepsi biaya pendidikan & $-0,138$ & 0,061 & $-2,249$ & 0,026 \\
R Square & & 0,538 & & \\
Adjusted $R$ Square & & 0,525 & & \\
F hitung & & 41,042 & \\
Signifikansi F & 0,000 & & \\
\hline
\end{tabular}

Sumber : Data diolah, 2018

Berdasarkan hasil analisis regresi linier berganda seperti yang disajikan pada Tabel 5, maka dapat dibuat persamaan regresi sebagai berikut:

$$
Y=0,209 X_{1}+0,300 X_{2}+0,247 X_{3}-0,138 X_{4}
$$

Nilai koefisien regresi masing-masing variabel bebas memiliki nilai signifikansi uji t kurang dari 0,05 . Hal ini menunjukkan bahwa semua variabel bebas memiliki pengaruh yang signifikan terhadap variabel terikat. Berikut penjelasan mengenai hasil analisis regresi berganda, terdiri atas koefisien determinasi $\left(\mathrm{R}^{2}\right)$, uji kelayakan model (uji F), dan uji hipotesis (uji t). 
Koefisien determinasi $\left(\mathrm{R}^{2}\right)$ digunakan untuk mengetahui dan mengukur kemampuan model dalam menerangkan variasi variabel independen. Besarnya pengaruh variabel bebas terhadap variabel terikat yang ditunjukkan oleh nilai determinasi total (R Square) sebesar 0,538 mempunyai arti bahwa sebesar 53,8\% variasi minat mahasiswa mengikuti pendidikan Magister Akuntansi dipengaruhi oleh variasi motivasi kualitas, motivasi karir, motivasi ekonomi, dan persepsi biaya pendidikansedangkan sisanya sebesar $46,2 \%$ djelaskan oleh faktor lain yang tidak dimasukkan ke dalam model.

Uji kelayakan model regresi bertujuan untuk mengetahui apakah minimal salah satu variabel bebas yang diidentifikasi (Motivasi kualitas, motivasi karir, motivasi ekonomi, dan persepsi biaya pendidikan) tepat digunakan memprediksi minat mahasiswa mengikuti pendidikan Magister Akuntansi. Uji ini sering juga disebut dengan uji F. Hasil pengolahan data pada Lampiran 9 dengan menggunakan program SPSS diperoleh nilai $F_{\text {hitung }}$ sebesar 41,042 dengan signifkansi sebesar $0,000<0,05$, maka dapat disimpulkan bahwa pada kelompok yang diuji memiliki perbedaan yang nyata (signifikan). Hasil ini mempunyai arti bahwa ada pengaruh signifikan antara motivasi kualitas, motivasi karir, motivasi ekonomi, dan persepsi biaya pendidikansecara simultan pada minat mahasiswa mengikuti pendidikan Magister Akuntansi.

Pengaruh variabel motivasi kualitas, motivasi karir, motivasi ekonomi, dan persepsi biaya pendidikan pada minat mahasiswa mengikuti pendidikan Magister Akuntansi diuji dengan menggunakan Uji t. Kriteria pengujian untuk menjelaskan interpretasi pengaruh antar masing-masing variabel yakni apabila nilai 
signifikansi $<0,05$ maka $\mathrm{H}_{0}$ ditolak dan $\mathrm{H}_{1}$ diterima. Sebaliknya, jika nilai signifikansi > 0,05 maka $\mathrm{H}_{0}$ diterima dan $\mathrm{H}_{1}$ ditolak.

Berdasarkan hasil analisis pengaruh motivasi kualitas pada minat mahasiswa mengikuti pendidikan Magister Akuntansi diperoleh nilai signifikasi sebesar 0,037 dengan nilai koefisien regresi positif sebesar 0,209. Nilai Signifikansi $0,037<0,05$ mengindikasikan bahwa $\mathrm{H}_{0}$ ditolak dan $\mathrm{H}_{1}$ diterima. Hasil ini mempunyai arti bahwa motivasi kualitas berpengaruh positif dan signifikan padaminat mahasiswa mengikuti pendidikan Magister Akuntansi.

Berdasarkan hasil analisis pengaruh motivasi karir pada minat mahasiswa mengikuti pendidikan Magister Akuntansi diperoleh nilai signifikansi sebesar 0,002 dengan nilai koefisien regresi positif sebesar 0,300. Nilai Signifikansi 0,002<0,05 mengindikasikan bahwa $\mathrm{H}_{0}$ ditolak dan $\mathrm{H}_{2}$ diterima. Hasil ini mempunyai arti bahwa motivasi karirberpengaruh positif dan signifikan pada minat mahasiswa mengikuti pendidikan Magister Akuntansi.

Berdasarkan hasil analisis pengaruh motivasi ekonomi pada minat mahasiswa mengikuti pendidikan Magister Akuntansi diperoleh nilai signifikansi sebesar 0,002 dengan nilai koefisien regresi positif sebesar 0,247. Nilai signifikansi 0,002 $<0,05$ mengindikasikan bahwa $\mathrm{H}_{0}$ ditolak dan $\mathrm{H}_{3}$ diterima. Hasil ini mempunyai arti bahwa motivasi ekonomi berpengaruh positif dan signifikan padaminat mahasiswa mengikuti pendidikan Magister Akuntansi.

Berdasarkan hasil analisis pengaruh persepsi biaya pendidikan pada minat mahasiswa mengikuti pendidikan Magister Akuntansi diperoleh nilai signifikansi sebesar 0,026 dengan nilai koefisien regresi negatif sebesar -0,138. Nilai 
signifikansi $0,026<0,05$ mengindikasikan bahwa $\mathrm{H}_{0}$ ditolak dan $\mathrm{H}_{4}$ diterima. Hasil ini mempunyai arti bahwa persepsi biaya pendidikan berpengaruh negatif dan signifikan padaminat mahasiswa mengikuti pendidikan Magister Akuntansi.

Hasil analisis menunjukkan bahwamotivasi kualitas berpengaruh positif dan signifikanpada minat mahasiswa mengikuti pendidikan Magister Akuntansi. Hal ini berarti bahwa semakin tinggi motivasi mahasiswa untuk meningkatkan kualitas pendidikannya maka akan semakin meningkatkan minat mahasiswa untuk melanjutkan pendidikan Magister Akuntansi. Begitu pula sebaliknya, semakin rendah motivasi mahasiswa untuk meningkatkan kualitas pendidikannya maka semakin rendah pula minat mahasiswa mengikuti pendidikan Magister Akuntansi tersebut.

Hasil penelitian ini mendukung hasil penelitian Devani (2015)yang menyatakan bahwa motivasi kualitas berpengaruh positif dan signifikan terhadap minat mahasiswa akuntansi dalam melanjutkan pendidikan magister akuntansi. Hasil penelitian ini juga sejalan dengan penelitian yang dilakukan oleh Verawati (2016) dan Yunerlya \& Siegel (2013) yang menyatakan motivasi kualitas berpengaruh positif terhadap minat mahasiswa mengikuti pendidikan profesi akuntansi.

Penelitian ini sesuai dengan teori kebutuhan McClelland yang menunjukkan bahwa setiap individu dapat termotivasi oleh kebutuhan untuk berprestasi (Ardana, 2009). Salah satu alasan seseorang bisa termotivasi dalam pengambilan keputusan adalah dalam rangka meningkatkan kualitas dan presetasinya (Robbins \& Judge, 2008). Kualitas dianggap suatu hal yang 
diperhatikan di dalam jenjang pendidikan. Semakin tinggi jenjang pendidikan yang telah ditempuh seseorang maka kualitas yang dimilikinya pun semakin baik. Motivasi kualitas dapat mempengaruhi minat seseorang dalam menempuh Magister Akuntansi dilihat dari banyak keuntungan yantg diperolehnya salah satunya yaitu dapat menjadi seorang dosen.

Hasil analisis menunjukkan bahwa motivasi karir berpengaruh positif dan signifikanpada minat mahasiswa mengikuti pendidikan Magister Akuntansi. Hal ini berarti bahwa semakin tinggi motivasi mahasiswa untuk meningkatkan karirnya maka semakin meningkat minat mahasiswa untuk mengikuti pendidikan Magister Akuntansi. Begitu pula sebaliknya, semakin rendah motivasi mahasiswa untuk meningkatkan karirnya,maka semakin rendah pula minat mahasiswa untuk mengikuti pendidikan Magister Akuntansi tersebut.

Hasil penelitian ini mendukung penelitian Zyl (2011) serta Devani (2015) yang menyatakan bahwa motivasi karir berpengaruh positif dan signifikan terhadap minat mahasiswa akuntansi mengikuti pendidikan magister akuntansi. Hasil penelitian ini juga sejalan dengan penelitian Dewi \& Mediatrix (2018) yang menyatakan motivasi karir berpengaruh positif terhadap minat mahasiswa akuntansi reguler dan non reguler Universitas Udayana mengikuti PPAk.

Penelitian ini sesuai dengan teori kebutuhan McClallend yang menyatakan bahwa salah satu dari tingkat kebutuhan manusia adalah kebutuhan untuk kekuasaan (Ardana, 2009). Karyawan yang memiliki dasar pendidikan akuntan yang lebih tinggi perlu waktu yang pendek untuk dipromosikan sebagai manajer (Aryani \& Erawati, 2016). Magister akuntansi merupakan salah satu tahap 
pendidikan yang dapat memotivasi peningkatan karir. Jadi, pendidikan magister akuntansi bisa menjadi salah satu faktor yang memotivasi peningkatkan karir. Seseorang akan meningkatkan karirnya jika termotivasi untuk meningkatkan status ekonomi dan kepuasan dirinya.

Hasil analisis menunjukkan bahwamotivasi ekonomi berpengaruh positif dan signifikan pada minat mahasiswa mengikuti pendidikan Magister Akuntansi. Hal ini berarti bahwa semakin tinggi motivasi mahasiswa untuk meningkatkan kemampuan ekonominya maka akan berpengaruh pada semakin meningkatnya minat mahasiswa untuk mengikuti pendidikan Magister Akuntansi. Begitu pula sebaliknya, semakin rendah motivasi mahasiswa untuk meningkatkan kemampuan ekonominya maka akan berpengaruh pada semakin berkurangnya minat mahasiswa mengikuti pendidikan Magister Akuntansi.

Hasil penelitian ini mendukung temuan penelitian Devani (2015) yang menunjukkan bahwa motivasi ekonomi berpengaruh positif pada minat mahasiswa akuntansi mengikuti pendidikan magister akuntansi. Hasil penelitian ini juga sejalan dengan penelitian yang dilakukan Aryani \& Erawati (2016) dan Widyastuti \& Juliana (2004) yang meperoleh hasil bahwa motivasi ekonomi berpengaruh positif terhadap minat mahasiswa mengikuti pendidikan profesi akuntansi.

Penelitian ini sesuai dengan teori McClelland yang menyatakan bahwa setiap individu memiliki kebutuhan akan kekuasaan termasuk kekuasaan keuangan (Ardana, 2009). Motivasi ekonomi adalah suatu dorongan yang timbul dari dalam diri seseorang untuk meningkatkan kemampuan pribadinya dalam 
rangka mencapai pengahargaan finansial yang dinginkannya. Secara umum penghargaan finansial terdiri atas penghargaan langsung dan tidak langsung. Penghargaan langsung meliputi pembayaran yang berasal dari upah dasar atau gaji pokok, upah lembur, atau pembagaian laba yang didapat perusahaan, sedangkan penghargaan tidak langsung meliputi asuransi, tunjangan-tunjangan, atau program pensiun (Dyastari \& Yadnyana, 2016).

Hasil analisis menunjukkan bahwa persepsi biaya pendidikan berpengaruh negatif dan signifikanterhadap minat mahasiswa mengikuti pendidikan Magister Akuntansi. Hal ini berarti bahwa semakin mahal persepsi biaya pendidikan yang diterima mahasiswa maka minat mahasiswa mengikuti pendidikan Magister Akuntansi akan semakin menurun. Begitu pula sebaliknya, semakin murah persepsi biaya pendidikan yang diterima mahasiswa maka minat mahasiswa mengikuti pendidikan Magister Akuntansi akan semakin meningkat.

Hasil penelitian ini mendukung temuan penelitian Berlinasari \& Erawati (2017) yang menemukan bahwa biaya pendidikan berpengaruh negatif pada minat mahasiswa akuntansi mengikuti pendidikan profesi akuntansi. Hasil penelitian ini juga sejalan dengan hasil penelitian Hadiprasetyo (2014) dan Sapitri \& Yaya (2015) yang memperoleh hasil bahwa biaya studi berpengaruh negatif signifikan terhadap minat mahasiswa melanjutkan pendidikan profesi akuntansi.

Penelitian ini sesuai dengan teori hukum permintaan yang menjelaskan tentang adanya hubungan yang bersifat negatif yang dikemukakan oleh Alfred Marshall yaitu, apabila harga naik maka jumlah barang yang diminta sedikit dan apabila harga rendah jumlah barang yang diminta meningkat (Aryani \& Erawati, 
I Gede Agus Dicky Surya B. dan I Gusti Ayu Nyoman Budiasih. Pengaruh ...

2016). Dengan demikian dapat disimpulkan bahwa semakin besar biaya pendidikan Magister Akuntansi yang dibebankan kepada mahasiswa maka semakin rendah minat mahasiswa akuntansi untuk mengikuti pendidikan Magister Akuntansi.

Penelitian ini menjelaskan Teori Kebutuhan McClelland dari variabel motivasi kualitas yaitu kebutuhan akan berprestasi, sedangkan variabel motivasi karir dan motivasi ekonomi menjelaskan kebutuhan akan kekuasaan. Penelitian ini juga menjelaskan teori hukum permintaan dimana persepsi biaya yang mahal dan tidak terjangkau oleh mahasiswa maka minat mahasiswa mengikuti pendidikan Magister Akuntansi semakin rendah.

Penelitian ini memberikan implikasi bagi program Magister Akuntansi di Fakultas Ekonomi Universitas Udayana sebagai pertimbangan dan pengetahuan mengenai minat mahasiswa mengikuti pendidikan Magister Akuntansi serta faktor-faktor yang memengaruhinya. Organisasi juga dapat mengevaluasi dan meningkatkan motivasi kualitas, motivasi karir, motivasi ekonomi, dan persepsi biaya pendidikanbagi mahasiswa karena hal tersebut dapat mempengaruhi minat mahasiswa mengikuti pendidikan Magister Akuntansi.

\section{SIMPULAN}

Motivasi kualitas berpengaruh positif pada minat mahasiswa mengikuti pendidikan magister akuntansi. Hal ini berarti bahwa semakin tinggi motivasi mahasiswa untuk meningkatkan kualitas pendidikannya maka akan semakin 
meningkatkan minat mahasiswa untuk melanjutkan pendidikan pada jenjang Magister Akuntansi.

Motivasi karir berpengaruh positif pada minat mahasiswa mengikuti pendidikan Magister Akuntansi. Hal ini berarti bahwa semakin tinggi motivasi mahasiswa untuk meningkatkan karirnya maka minat mahasiswa untuk mengikuti pendidikan Magister Akuntansi akan semakin bertambah.

Motivasi ekonomi berpengaruh positif pada minat mahasiswa mengikuti pendidikan Magister Akuntansi. Hal ini berarti bahwa semakin tinggi motivasi mahasiswa untuk meningkatkan kemampuan ekonominya maka akan berpengaruh pada semakin meningkatnya minat mahasiswa untuk mengikuti pendidikan Magister Akuntansi.

Persepsi biaya pendidikan berpengaruh negatif pada minat mahasiswa mengikuti pendidikan Magister Akuntansi. Hal ini berarti bahwa semakin mahal dan tidak terjangkau persepsi biaya pendidikan yang dibebankan pada mahasiswa maka minat mahasiswa mengikuti pendidikan Magister Akuntansi akan semakin menurun.

Perguruan tinggi selalu memperkenalkan tentang profesi akuntan dan Magister Akuntansi kepada peserta didik sejak dini. Perguruan tinggi perlu untuk menjelaskan lebih dalam lagi akan keuntungan pendidikan akuntansi dari segi peningkatan kualitas, peningkatan jenjang karir maupun peningkatan kemampuan ekonomi agar nantinya hasil yang mahasiswa peroleh dari mengikuti pendidikan Magister Akuntansi dapat sesuai dengan harapan dan motivasi awal yang dimiliki. 
Penelitian berikutnya juga dapat menambah variabel-variabel lain karena hasil koefisien determinasi sebesar 53,8\% sedangkan sisanya sebesar 46,2\% dipengaruhi oleh faktor lain seperti faktor lingkungan eksternal yang meliputi keluarga dan kelompok referensi, faktor strategi komunikasi yang meliputi seminar, pameran dan faktor lainnya.

\section{REFERENSI}

Andrian, I. (2001). Panduan Pengembangan Organisasi. Yogyakarta: Andi.

Ardana, K. (2009). Perilaku Keorganisasian. Yogyakarta: Graha Ilmu.

Aryani, N. P. D., \& Erawati, N. M. A. (2016). Pengaruh Motivasi Kualitas, Karir, Ekonomi, dan Biaya Pendidikan Pada Minat Mahasiswa Mengikut Pendidikan Profesi Akuntansi. E-Jurnal Akuntansi Universitas Udayana, 16(1), 362-387.

Berlinasari, M., \& Erawati, N. M. A. (2017). Pengaruh Motivasi, Biaya Pendidikan dan Lama Pendidikan Pada Minat Mahasiswa Akuntansi Mengikuti PPAk. E-Jurnal Akuntansi Universitas Udayana, 21(1), 447-476.

Bozek, B., Raeymaeckers, P., \& Spooren, P. (2017). Motivations to become a master in social work: a typology of students. European Journal of Social Work, 20(3), 409-421. https://doi.org/10.1080/13691457.2017.1283587

Devani, R. (2015). Pengaruh Motivasi Terhadap Minat Mahasiswa Akuntansi dalam Melanjutkan Studi Pascasarjana Magister Akuntansi. Jurnal Akuntansi.

Dewi, I. A. R. P., \& Mediatrix, M. (2018). Persepsi Mahasiswa Akuntansi Reguler dan Non Reguler Universitas Udayana Terhadap Minat Mengikuti Pendidikan Profesi Akuntansi. E-Jurnal Akuntansi Universitas Udayana, 25(3), 2242-2268.

Durso, S. D. O. (2016). Motivational Factors for the Master's Degree : a Comparison between Students in Accounting And Economics in the Light of the Self- Determination Theory, 27, 243-258. https://doi.org/10.1590/1808$057 \times 201602080$

Dyastari, N. P. S., \& Yadnyana, I. K. (2016). Pengaruh Motivasi Pada Minat Mahasiswa Non Akuntansi Untuk Mengikuti Pendidikan Profesi Akuntansi. 
E-Jurnal Akuntansi Universitas Udayana, 16(1), 333-361.

Ghozali, I. (2016). Aplikasi Analisis Multivariate dengan Program IBM SPSS 23. Semarang: BPFE Universitas Diponegoro.

Gibson, M. (2008). Manajemen Sumber Daya Manusia (2nd ed.). Jakarta: Erlangga.

Hadiprasetyo, T. (2014). Pengaruh Motivasi, Persepsi Biaya Pendidikan dan Persepsi Masa Studi Terhadap Minat Mahasiswa Prodi Akuntansi Fakultas Ekonomi Universitas Negeri Yogyakarta Untuk Mengikuti Pendidikan Profesi Akuntansi.

Halim, A. (2012). Akuntansi Sektor Publik Akuntansi Keuangan Daerah. Jakarta: Salemba Empat.

Ismail, M., \& Lestari, E. (2013). Pengaruh Motivasi Terhadap Minat Mahasiswa Akuntansi Untuk Mengikuti Profesi Akuntansi (PPAk). Jurnal Keuangan Dan Bisnis, 4(2).

Johnson, E. B. (2009). Contextual Teaching \& Learning Menjadikan Kegiatan Belajar Mengajar Mengasisyikkan dan Bermakna. Bandung: MLC.

Kompas. (2013). Penting Enggak Sih Lanjut Studi S-2? Retrieved from http:/kompas.com. Diakses 20 Oktober 2018

Kompas. (2018). Dosen Milenial Disiapkan. Retrieved from https://kompas.id/baca/humaniora/2018/10/31/dosen-milenial-disiapkan/.

Diakses 2 Desember 2018

Kusumawati, R., \& Waluyo, I. (2013). Pengaruh Motivasi dan Pengetahuan UU No. 5 Tahun 2011 tentang Akuntan Publik pada Minat Mahasiswa Akuntansi mengikuti PPAk. Nominal, 2(2), 1-30.

Mulyadi. (2015). Akuntansi Biaya (5th ed.). Yogyakarta: Sekolah Tinggi Ilmu Manajemen YKPN.

Purnamasari, D. (2017). Lulusan Mana yang Banyak Mencetak Pengangguran? Retrieved from https://tirto.id/lulusan-mana-yang-banyak-mencetakpengangguran-cwxY. Diakses 3 Desember 2018

Robbins, S. P., \& Judge, T. A. (2008). Perilaku Organisasi (2nd ed.). Jakarta: Salemba Empat.

Sapitri, Z., \& Yaya, R. (2015). Faktor-Faktor yang Berpengaruh Terhadap Minat Mahasiswa Untuk Mengikuti PPAk. Jurnal Ilmiah Universitas 
Muhammadiyah Yogyakarta, 16(1), 51-52.

Siegel, G., \& Marconi, H. R. (1989). Behavioral Accounting. International Journal of Humanities Dan Social Science, 5(7).

Silalahi, U. (2009). Metode Penelitian Sosial. Bandung: PT. Refika Aditama.

Simamora, B. (2001). Memenangkan Pasar dengan Pemasaran Efektif dan Profitabel. Jakarta: PT. Gramedia.

Tjiptono, F. (2004). Manajemen Jasa (1st ed.). Yogyakarta: Andi.

Verawati, D. (2016). Pengaruh Motivasi, Akreditasi Prodi, Fasilitas Pendidikan, Konsentrasi Jurusan, Biaya Pendidikan Dan Reputasi Pendidik Terhadap Minat Mahasiswa Untuk Melanjutkan Magister Akuntansi (Studi Empiris Pada Mahasiswa Akuntansi di UMS).

Widyastuti, S., \& Juliana. (2004). Pengaruh Motivasi Terhadap Minat Mahasiswa Akuntansi Untuk Mengikuti Pendidikan Profesi Akuntansi (PPAk). SNA VII, 320-339.

Wijaya, B. K. (2010). Cara Cerdas Pilih Jurusan Demi Profesilmpian. Yogyakarta: Jogja Great Publisher.

Yunerlya, N. E., \& Siegel, L. (2013). Pengaruh Motivasi, Persepsi dan Lama Pendidikan Terhadap Minat Mahasiswa untuk Mengikuti Pendidikan Profesi Akuntansi, 13(1), 69-77.

Zyl, V. (2011). Why Some Students Choose to Become Chartered Accountants (And Others Do Not). Meditari Accountancy Research, 19(1), 56-74. 